\title{
Editorial
}

\section{Biologics-An Open Access Journal for Biological Drugs}

\author{
Raffaele Capasso (D)
}

Citation: Capasso, R. Biologics-An Open Access Journal for Biological

Drugs. Biologics 2021, 1, 1.

https: / / doi.org/10.3390/

biologics1010001

Received: 20 February 2021

Accepted: 8 March 2021

Published: 11 March 2021

Publisher's Note: MDPI stays neutral with regard to jurisdictional claims in published maps and institutional affiliations.
Department of Agricultural Sciences, University of Naples Federico II, 80055 Portici, NA, Italy; rafcapas@unina.it

Biological drugs have been attracting interest from the scientific community in recent years. In fact, although the pharmaceutical industry will remember 2020 as the year of COVID-19, it was also the year when the US Food and Drug Administration (FDA) authorized 13 biological drugs (biologics). These data should make us reflect on how biologics can help to fight new pathologies [1].

Biological drug products are medicinal products that contain one or more active ingredients produced or extracted by a biological system such as enzymes, blood products, hormones, peptides, cytokines, fusion proteins, monoclonal antibodies and next-generation antibody formats such as drug-antibody conjugates, bispecific antibodies, single-chain variable fragments, vaccine components and gene therapy vectors [2].

Biological drugs have produced extraordinary results in the treatment of diabetes, Crohn's disease, ulcerative colitis, rheumatoid arthritis, hepatitis, anemia, multiple sclerosis and cancer etc. Biologics, by altering the processes that regulate the disease, explicate their action.

What are the advantages of biologics?

(i) high specificity and affinity;

(ii) long-acting pharmacokinetics;

(iii) less toxicity and side effects, but close to these advantages, very expensive development and production.

To divulge research on biologics drugs, Biologics (ISSN 2673-8449) was born, an open access international journal by MDPI (Basel, Switzerland).

The topics of interest of this journal include, but are not limited to, the following: vaccines, hormones, cytokines and allied mediators, diagnostics, gene therapy, cytology, tissues, thrombolytic agents, monoclonal antibodies, blood and blood components, allergenics, downstream processing, general bacteriology, general virology, endogenous, and adventitious viruses, molecular biology, parasitology, prion and prion disease, protein chemistry, toxins, and toxoids.

On behalf of the entire editorial board, I invite you to submit your exciting research to Biologics and look forward to contributions from all fields related to biological medicine. I wish great success for Biologics.

Funding: This research received no external funding.

Conflicts of Interest: The author declares no conflict of interest.

\section{References}

1. de la Torre, B.G.; Albericio, F. The Pharmaceutical Industry in 2020. An Analysis of FDA Drug Approvals from the Perspective of Molecules. Molecules 2021, 26, 627. [CrossRef] [PubMed]

2. Narayanan, H.; Dingfelder, F.; Butté, A.; Lorenzen, N.; Sokolov, M.; Arosio, P. Machine Learning for Biologics: Opportunities for Protein Engineering, Developability, and Formulation. Trends Pharmacol. Sci. 2021, 42, 151-165. [CrossRef] [PubMed] 